\title{
Integrative phenomena in visual arts and mathematics
}

\section{Portaankorva-Koivisto, Päivi}

2019-04-03

Portaankorva-Koivisto , P \& Havinga , M 2019 , ' Integrative phenomena in visual arts and mathematics ' , Journal of Mathematics and the Arts , vol. 13 , no. 1-2 , pp. 4-24 . https://doi.org/10.1080/17513472.2

http://hdl.handle.net/10138/313874

https://doi.org/10.1080/17513472.2018.1504269

unspecified

acceptedVersion

Downloaded from Helda, University of Helsinki institutional repository.

This is an electronic reprint of the original article.

This reprint may differ from the original in pagination and typographic detail.

Please cite the original version. 


\section{Integrative phenomena in visual arts and mathematics}

Päivi Portaankorva-Koivisto ${ }^{1} \&$ Mirka Havinga $^{2}$

${ }^{1}$ Faculty of Educational Sciences, University of Helsinki, Finland

${ }^{2}$ Sydän-Laukaa School, Jyväskylä, Finland

paivi.portaankorva-koivisto@helsinki.fi 


\title{
Integrative phenomena in visual arts and mathematics
}

\author{
Päivi Portaankorva-Koivisto ${ }^{1} \&$ Mirka Havinga ${ }^{2}$ \\ ${ }^{1}$ University of Helsinki, ${ }^{2}$ Sydän-Laukaa School, Jyväskylä
}

\begin{abstract}
The aim of our article is to find suitable integrative phenomena for both visual arts and mathematics, with a focus on preserving the nature of each of these subjects and their specific methods of acquiring and processing information. This article builds a picture of how to design and conduct an integrative learning continuum which genuinely preserves the nature of mathematics. To draw conclusions, we combined datasets from mathematics teacher education and the lower secondary school context. We found out that suitable integrative phenomena can relate to concepts shared by each of the integrating disciplines, such as ratio; or they can be typical processes of knowledge acquisition and construction, such as sorting. The teaching experiments revealed that the integrative phenomena appropriate for use in school must enable a joint investigative learning experience. The third finding was that the pupils needed teacher support to view the subjects more broadly.
\end{abstract}

Keywords: mathematics; visual arts; integrative phenomena

\section{Introduction}

The Finnish national core curriculum for basic education, determined by the Finnish National Board of Education, has recently been reformed, and the new curriculum was introduced to the lower grades in August 2016, and the upper grades in August 2017. It includes the objectives and core contents of different subjects, as well as the principles of pupil assessment, special-needs education, pupil welfare and educational guidance. The core curriculum also addresses the principles of a good learning environment, working approaches and the concept of learning. The reform emphasises collaborative classroom practices that include interdisciplinary and phenomenon- and project-based studies, in which several teachers may work together with the pupils. The main focus is on increasing curiosity and motivation, and combining knowledge and skills from different subjects, therefore enhancing understanding and multiliteracy [5].

One central aim of the new Finnish National Core Curriculum for compulsory basic education is the interdisciplinary study of phenomena. Schools are required to design and provide at least one such study period per school year for all pupils. This is part of a larger whole that focuses on developing organisational culture and learning communities, and generating innovative learning environments and working approaches [1]. In secondary schools, discipline-based integration offers a way in which to organise integrative learning continuums. Tani, Juuti and Kairavuori [27] have raised the question of what the appropriate level of subject-specific knowledge might be in order to teach subjects in an integrated curriculum (see also [17]).

This article discusses phenomenon- and project-based integrated teaching and learning, as implemented in visual arts and mathematics, and the goal of preserving the nature of these disciplines and their typical working methods. Our conclusions are based on the combination of datasets from mathematics teacher education and the lower secondary school context. Firstly, we identify phenomena that enable teachers to design and construct discipline-based integration and interdisciplinary learning continuums and to create conditions for building broad, open and collaborative classroom practices. Secondly, we examine how to describe phenomena that are of interest to pupils and at the same time clarify the nature and traditions of the disciplines involved. Thirdly, we discuss how mathematics manifests itself in the learning continuums realised in this study.

To clarify the authors' viewpoints, we note that Mirka Havinga is a subject teacher who teaches both visual arts and mathematics at the lower secondary school of Sydän-Laukaa in Central Finland. At the beginning of her career she taught these subjects separately, but her professional development and interests 
have led her to explore the questions 'What is artistic mathematics?' and 'What is mathematical art?'. She asks herself 'What kind of pedagogy genuinely combines these subjects?' and actively designs teaching experiments to find answers to these questions. Päivi Portaankorva-Koivisto is a mathematics teacher educator, and works at the University of Helsinki. Music in particular has contributed to her views on arts and mathematics. She is dedicated to developing experiential mathematics teaching and learning. She hopes that her teacher students and their future pupils will be able to experience mathematics as their own, and emphasises investigative methods, curiosity and agency.

In our view, the discipline-based integration in teaching can be implemented by placing the concepts and processes of the different subjects side by side and comparing them. This aims to provide a deep understanding of the structure of each discipline. Therefore, this article first examines the different methods of integration, particularly in visual arts and mathematics. Second, as in this article, we address the specific issues in mathematics teaching and learning in this article, it examines how concepts and processes are taught and learned in mathematics.

\section{Integrated phenomenon-based teaching}

In integrated teaching, either the disciplines involved or the phenomenon itself are the essential starting point [4]. Teachers discuss the extent to which different disciplines and art forms constitute the basis for planning instruction. If integration is unidisciplinary [20], the teaching draws from a single discipline, and integrates the contents and themes within one subject. Multidisciplinary integration draws from several disciplines contributing to a particular theme, but these are taught separately. Gresnigt, Taconis, van Keulen, Gravemeijer \& Baartman [5] present the approaches of integration in the form of a staircase with six steps. In fragmented integration, all disciplines are taught separately and integration is only realised occasionally. In connected integration, the teacher deliberately makes connections between the subjects. Nesting is an intermediate approach to integration: here one subject enriches another. On the staircase, multidisciplinary integration still preserves the goals of the individual disciplines. In interdisciplinary integration, the disciplines' perspectives are lost; and in transdisciplinary integration, the focus is completely on the phenomenon.

Unidisciplinary integration is one of subject teachers' main cornerstones when they plan their instruction. Different themes, concepts and processes must be linked to promote learning. Integration between subjects also requires planning in co-operation with other teachers, and organisation of teaching. As teachers have found common themes, these can be taught 1) sequentially with one subject preceding the other, 2) as parallel bridging links between the subjects, 3) partially together and partially as separate disciplines in the same classes, 4) through enhancing and enriching another subject or 5) together, equally. (See [8], [6], and [15].)

When teachers plan their teaching in co-operation, the themes can act as their lead. Another possible starting point may be the students; their experiences, interests and questions [9]. Then the teacher's goal is to help the students make connections between what they have learned and the real world. The teacher can encourage the students to organise their experiences and find regularities around them [20]. In this situation, integration is more than a structural arrangement. It focuses on real problems and authentic questions [1], and builds on meaningful learning continuums [14]. Beane highlights [1] that integrated themes can be designed by teachers, but ideally students can design them themselves.

One method of integration is to start from the school community's goals and atmosphere [9]. Fogarty [6] suggests that integration, whether it is implemented within the subject as nested or between the subjects as threaded, can be based on promoting social skills, thinking skills, learning skills or technology skills. In this situation, metaskills are more important than the knowledge and skills of the disciplines to be merged. 
Bresler [2] observed in her studies that arts can be taught in an interdisciplinary manner in four ways. She calls these subservient integration, affective integration, social integration and co-equal integration. The most common way is to 'flavour' the other subject by means of art. In mathematics, this flavouring can manifest itself in geometric drawing. These tasks are, however, quite mechanical and do not develop aesthetic awareness, critical review or specific artistic skills. Another way often used to integrate art with other subjects is to change mood and creativity, for example, by playing music in the background. In mathematical activities, background music can provide a change of pace, a change of mode, or a change of mood. The third way is to build social interaction and inclusion through art. According to Bresler [11], none of these three methods of integration required discipline-specific knowledge or skills of the teacher. Only seldom was the integration realised equally and cognitively in a meaningful way within the subjects. In the fourth way of integrating art with other subjects, co-equal integration, however, the tasks necessitate higherorder cognitive skills as well as aesthetic qualities. This method of integration was the least common in her study.

\section{Project-based integrated learning in visual arts and mathematics}

For integrating visual arts and mathematics, Räsänen [21] suggests a model based on observations, emotions, forms representing each discipline, and cultural symbols. In the teaching and learning process, knowledge gained from observations and emotions is connected to conceptual and cultural knowledge. In investigational, experiential mathematics teaching and learning these elements are also central [18]. When we observe a line in mathematics, for example, we differentiate between a straight line and a curved line; we make notions about its slope and dimensions; we make connections with geometry, namely analytic geometry; we consider the properties and we enter into mathematical language and society. When we observe a line in visual arts, it is one of the basic elements, we notice its thickness and length, its place, the tool used, and we recognise the ongoing process. We can analyse how it expresses moods and feelings, how it communicates ideas. We are perhaps able to associate it with some artist or an era.

According to Räsänen [21], learning in visual arts requires an ability to identify the specific characteristics of a phenomenon and moreover, to discover how these features could be illustrated or visualised and what kinds of metaphorical meanings they hold. Activities can either produce something or interpret others' artistic work. Quite often, the knowledge behind a work of art is tacit, and understanding or interpreting the work requires a fine-grained ability to distinguish relations and cultural symbols. Accordingly, we can talk about investigative learning in visual arts [21].

In mathematics, investigative learning is often understood as a synonym for problem-solving and inquiry-based mathematics. In this paper, by investigative learning we mean that pupils have opportunities to work with non-routine mathematical problems or unfamiliar situations, individually or collaboratively, and thereby develop their own meaningful solutions [16]. When working on problem-solving tasks, pupils learn what 'different' means in terms of solutions, and how to produce different solutions. In this case we can talk about agency, i.e. pupils' own mathematics, which is nevertheless located within the cultural framework shaped by the mathematics community [18].

\section{Concepts and processes in learning mathematics}

In mathematics, the learning of concepts and processes are complementary. In fact, many mathematical concepts also include the processes. Sfard [23] takes symmetry as an example. This can be conceived as a static property of a geometric form, but also as a process, a transformation, an algorithm, and an action. Accordingly, a number or a function can be understood in two fundamentally different ways: structurally as objects, and operationally - as processes [23]. Two common views of learning mathematics are the 'dual 
nature of mathematical conceptions' presented by Anna Sfard [23], and the 'three worlds of mathematics' by David Tall [24].

Sfard [23] suggests that in the process of concept formation, operational conceptions precede the structural. A graphic representation of the function or writing down a number are both just one of many ways in which to describe an abstract concept or an idea that we cannot see. An essential component of mathematical ability is indeed to be able to see these invisible objects. Sfard [23] states that in a historical sense, in computational mathematics a number originates from the process of counting; in fact the majority of mathematical ideas originated in processes rather than in objects. An intricate interplay between operational and structural conceptions of the same notions is a prerequisite for learning mathematics and mathematical problem-solving [23].

Tall [24] describes learning mathematical concepts and processes using three worlds of mathematics. The 'embodied world' includes both our mental perceptions of objects and internal conceptions that involve visuospatial imagery. In this world, something is true because we can perceive and sense it to be true. The second world is the world of symbols, the 'proceptual world'. By using symbols, we are able to switch from processes to doing mathematics and from concepts to thinking about mathematics [25]. What is true is true because we are able to show it to be true by symbolic manipulation. The third world is based on properties. In this world, we are able to express mathematical ideas in terms of formal definitions, axioms and structures. This world is called the 'formal world'. Within the axiomatic system, we build new concepts and theories, and what is true is true because we can prove it to be true [24], [25]. When we learn mathematics, we take different journeys through these three worlds and we reconsider and reconstruct our existing ideas. These are called, according to Tall [26], 'met-befores', which are sometimes consistent with the new situation but at other times inconsistent.

Font, Godino, and Gallardo [7] argue that school usually offers students a descriptive/realist view of mathematics. The teaching-learning process passes through the stages of manipulation with hand-on materials, graphical representation and symbolic representation. In various activities, the pupils progress from operating with physical objects to operating with mathematical objects. They learn properties that they implicitly assume to be properties of mathematical objects, and procedures that they assume to be rules about how to use these mathematical objects [7].

The question arises as to whether multidisciplinary learning continuums could enrich students' perceptions of mathematics and open up the characteristics of mathematical concepts and processes.

\section{Searching for phenomena to integrate visual arts and mathematics}

In this paper, we search for phenomena that integrate visual arts and mathematics. Our results shed new light on practical curriculum integration and the challenges that this presents for teacher preparation.

Our research questions are:

(1) What kind of phenomena can integrate visual arts and mathematics?

(2) What kind of integrative activities can a visual arts and mathematics teacher implement in their lessons with lower secondary pupils (age 13 to 15 years)?

(3a) What mathematics did the pre-service mathematics teachers and pupils recognise and name from these four integrative activities?

(3b) What was the meaning of these integrative learning continuums for the pupils? 


\section{Data sets and analyses}

In this section, we introduce the datasets that we collected and the analyses that we carried out. In addressing our research questions, we first explore what kind of phenomena could be called mathematical phenomena. In autumn 2015, we conducted a survey at the University of Helsinki at the beginning of a mathematics student teachers' meeting on curriculum integration. The students were invited to think about the topic individually and answer an open question: 'What are mathematical phenomena?' The students were told that they do not have to return the form if they do not wish to participate in the study. In total, 51 returned their forms [10]. This question was very open as we did not want the students to focus too much on textbooks or calculation skills. When designing and implementing teaching that integrates various subjects, the teachers should start by respecting each other's subjects. A well-chosen phenomenon is a good starting point.

In the analysis, we transcribed the survey responses into an electronic format, and qualitatively analysed this, using the grounded theory approach. In the first phase of the analysis we looked for descriptive words (marked below in different text styles), and found as many as 52 in total.

\#23

I can't give any example of a particular mathematical phenomenon, but it would be natural to combine it with logical reasoning: architecture, golden section in nature and art.

We used these descriptive words as a tool for categorising the data (see Table 1). The final table consisted of 202 excerpts from the data.

Table 1: Example of analysis of pre-service mathematics teachers' responses.

\begin{tabular}{ccl} 
Frequency & Descriptive word & \multicolumn{1}{c}{ Excerpts from data } \\
\hline 5 & modelling & $\begin{array}{l}\text { mathematically modelled, modelling disease, mathematically } \\
\text { modelling, can be modelled, can be modelled }\end{array}$ \\
7 & art & $\begin{array}{l}\text { from art, from visual art, art, visual art, in visual art, from visual art, } \\
\text { in visual art } \\
\text { observations, the differences and similarities of observations, } \\
\text { observation, visually observable }\end{array}$ \\
\hline
\end{tabular}

We established three categories: 1) Internal phenomena of mathematics, 2) Mathematical phenomena in nature and 3) Mathematical phenomena in cultural settings.

To answer the second research question 'What kind of integrative activities can a visual arts and mathematics teacher implement in their lessons with lower secondary pupils?' we introduced four teaching experiments that the second author had conducted in a Finnish lower secondary school in 2014-2015. Three classes took part in these experiments. The $7^{\text {th }}$ grade class $(20$ pupils $)$ participated in the first two experiments in autumn 2014, the third experiment was conducted in the $9^{\text {th }}$ grade class (19 pupils) in spring 2015 , and another $7^{\text {th }}$ grade class (21 pupils) took part in the fourth experiment in autumn 2015 . The teacher implemented action research on the basis of the national curriculum for the lower secondary grades. She 
planned and carried out the teaching, videotaped some of the learning situations, and kept a diary of her own and the pupils' work. She also collected pupils' written and visual artefacts as data (see [10], [11], [12] and [13]).

In the analysis, we classified the four integrative teaching experiments in three phases. In the first phase, we used the previously presented literature and looked at the structure and characteristics of how the integration was implemented in each of these experiments. In the second phase, we surveyed the mathematical concepts and processes that materialised in these experiments. In the third phase, we searched for the concepts and processes from visual arts that were realised in these experiments.

To answer the research question 'What mathematics did the pre-service mathematics teachers and pupils recognise and name in these four integrative activities?' we collected two sets of research materials in autumn 2016. Altogether 49 mathematics teacher students at the University of Helsinki were introduced to these previously mentioned four teaching experiments, via photos. During the presentation, each teacher student could contemplate what mathematics they recognised from these experiments and write these thoughts down. After the presentation, the teacher students worked in small groups (nine groups altogether), and while they were talking, took notes of the discussion. All the notes were collected as data.

In the analysis, the notes were transcribed into electronic format, and qualitatively analysed using the grounded theory approach. In the first classification, we found 76 different words and the total sum of the words was 239. After the second classification, the words were categorised into: 'concept' words and 'process' words. The Concept category had 41 different items and 163 mentions altogether. The Process category had 35 items and 76 mentions. After condensing the analysis further, we found seven categories: (1) concepts related to geometry, (2) concepts related to numbers, (3) the concept of ratio, (4) the concept of set, (5) the concept of quantity, (6) the concept of function and (7) the concept of infinity. We also condensed the processes into four categories: (1) working mathematically, (2) geometrical methods, (3) working with numbers and (4) others.

At the Sydän-Laukaa school, the 16 pupils who had participated in the previously mentioned learning continuums in the $7^{\text {th }}$ grade were now in the $9^{\text {th }}$ grade, and looked at photos of these teaching experiments and both their own and other pupils' work. They then answered a questionnaire. Ten girls and six boys returned the questionnaire. The questionnaire contained the same question 'What mathematics can you recognise in these experiments?'. It also included questions on the learning continuums, the effectiveness of the experiments, and student motivation. To consider the research question 'What was the meaning of these integrative learning continuums for the pupils?', we looked closer at the following three questions: (1) Has visual art and mathematics integrated instruction changed your views of mathematics? (2) How have these experiments influenced the way in which you see mathematics around you? and (3) What do you think of the integrated instruction of visual arts and mathematics.

In the analysis, the pupils' answers to the question 'What mathematics could you see in these learning continuums? were classified into two categories: concepts and processes. We found 12 different concepts with altogether 44 mentions, and 8 processes with 17 mentions.

The pupils' answers to open questions were transcribed and classified. As regards the question 'Has visual arts and mathematics integrated instruction changed your views of mathematics?' three categories were found: (1) My view expanded, (2) It did not effect on my view and (3) Other comments. Answers to the question 'How have these experiments influenced the way in which you see mathematics around you?' also fell into three categories: (1) I see more mathematics around me, (2) It made no impact and (3) Other comments. Again, the answers to 'What do you think of the integrated instruction of visual arts and mathematics?' came under three categories: (1) I don't agree with the idea of integrating subjects, (2) I agree with the idea of integrating visual arts and mathematics, (3) I agree with the idea of integrating subjects. 


\section{What are mathematical phenomena?}

The pre-service mathematics teachers' suggestions for mathematical phenomena were summarised into categories that proved to be almost equal in size. The first category 'Internal phenomena of mathematics' (28\%) comprised mathematical entities such as regularities, linearity, periodicity, convergence, infinity, patterns, logical reasoning, symmetry and problem-solving etc. In the second category 'Mathematical phenomena in nature' (34\%), student teachers mentioned mathematical events; observations; natural, chemical and physical phenomena; geometric phenomena, and examples such as the golden section, fractals, constellations, the annual rings in trees and snowflakes. In the third category 'Mathematical phenomena in cultural settings' (38\%), mathematical phenomena such as currency, finance, taxation, wages, music, art, probabilities, games, models, architecture, construction and building, cooking and travelling were mentioned.

The mathematics student teachers' survey revealed that when integrating visual arts and mathematics abstract concepts, the links between them are the key components of success. As regards mathematics, integrative learning continuums might include phenomena that are based on mathematical features such as structures, regularities, dependencies or relations. On the other hand, the dynamic phenomena and processes used when collecting and working with mathematical information are also interesting. These include, for example, logical reasoning, problem-solving and proofs. Another interesting approach to constructing integrative learning continuums and simultaneously maintaining the inherent working methods of mathematics is to explore phenomena occurring in organic nature or in cultural settings. These can most often be modelled and described using mathematical instruments. It should be noted that we are also able to generate mathematical phenomena such as music, architecture and art, as well as manage social and economic phenomena with mathematical tools.

\section{Four teaching experiments integrating visual arts and mathematics}

In this section, we introduce the four teaching experiments that Mirka Havinga has designed for implementing integrative learning continuums in lower secondary schools. The themes directly follow the mathematics and visual arts curricula. As the purpose of the teaching was to deepen the understanding of the mathematical content at hand, we consciously ensured that the work remained focused on this. However, the teaching was organized in a new way, combining the subjects and highlighting the experiential approach and the perspectives related to the identity work that is central to arts education.

\section{Personal meanings when producing and interpreting integers}

The 'integer' is one of the key topics in the curriculum of $7^{\text {th }}$ grade mathematics teaching and learning, and is normally introduced at the beginning of the autumn term. The goal for the experiment was to create personal meanings and interpret integers. This was first explored in the mathematics class by asking pupils to form sets of numbers. The pupils worked in small groups of three or four. Their task was to choose at least five numbers or symbols from the following list $(1,-5,4,7,32,8,11, \infty, 13,-10,-1,0,49,64)$, and to logically and precisely justify their selection. We then interpreted the pupils' answers together with them, using Brown's [3] categorisation (p. 151): 1) Apperceptual scheme - the object itself, 2) Appresentational scheme - the object seen as a sign, 3) Referential scheme - the thing signified and 4) Interpretational scheme - the connection between sign and signified [25]. During the group activity, the pupils placed numbers into categories (Table 2). As regards the object itself, the category remained empty, while the majority of sets were placed into the 'connection between sign and signified' category. The pupils' grounds for selecting this category were mathematical. 
Table 2: Frequencies and examples of sets of numbers presented by pupils.

\begin{tabular}{|c|c|c|}
\hline Category & $f$ & $\begin{array}{l}\text { Examples of sets of numbers } \\
\text { presented by pupils }\end{array}$ \\
\hline $\begin{array}{l}\text { Apperceptual scheme }- \text { the } \\
\text { object itself }\end{array}$ & 0 & \\
\hline $\begin{array}{l}\text { Appresentational scheme - } \\
\text { the object seen as a sign }\end{array}$ & 7 & $\begin{array}{l}\text { 'single-digit numbers' } \\
\text { 'all figures have circular forms' }\end{array}$ \\
\hline $\begin{array}{l}\text { Referential scheme }- \text { the } \\
\text { thing signified }\end{array}$ & 3 & $\begin{array}{l}\text { 'consecutive numbers' } \\
\text { 'numbers between zero and infinity' }\end{array}$ \\
\hline $\begin{array}{l}\text { Interpretational scheme - } \\
\text { the connection between sign } \\
\text { and signified }\end{array}$ & 14 & $\begin{array}{l}\text { 'numbers are every fifth number' } \\
\text { 'previous number is divided by two' } \\
\text { 'all the numbers are positive' } \\
\text { 'none of the numbers can be divided by two' }\end{array}$ \\
\hline
\end{tabular}

The pupils' work then continued in the visual arts lesson. This time the task was to choose an integer and then to visualise it on $20 \times 20 \mathrm{~cm}$ paper by either drawing or painting it. If there was enough time, an extra task was to visualise the opposite number. The thinking process in this task thus differed from the first task. The pupils' work was then categorised, together with the pupils, using the same categorisation they had learned in their mathematics lesson. The drawings in Figure 1 show how the pupils approached their own number in many different ways. The first drawing clearly illustrates the number itself as well as its numerical value. The second drawing represents the shape of the number in the form of swans' necks, as well as its numerical value in several instances. Many pupils chose a number representing a system, such as money, shoe size, awards or a temperature scale. In one drawing, the chosen number 3 was displayed along with its numerical value, its ordinal number, and metaphorical meanings of the number taken from wellknown fairy tales.

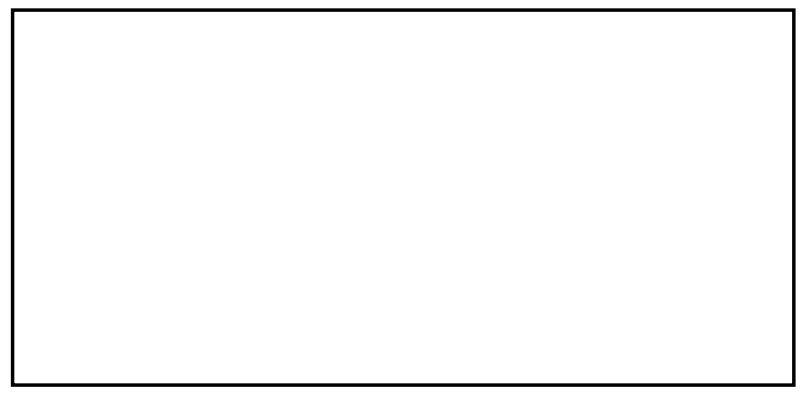

Figure 1: Examples of pupils' drawings derived from the first theme of the teaching experiment:

'Creating personal meanings and interpreting integers'. 
During the lesson, the pupils' work was organised on a number line, and concepts such as opposite number and infinity were discussed. Later, when the teacher reflected on the results of the pupils' work, she noticed that the drawings clearly differed from each other, ranging from literal examples to abstract interpretations, and from personal to common understandings of the information presented. Some drawings were easy to interpret, others more personal to the artist. Some drawings clearly presented a commonly known system whereas others presented personal interpretations of them. The teacher arranged the pupils' work on the school wall along two axes: Personal knowledge - common knowledge, and Personal conception - known system (Figure 2).

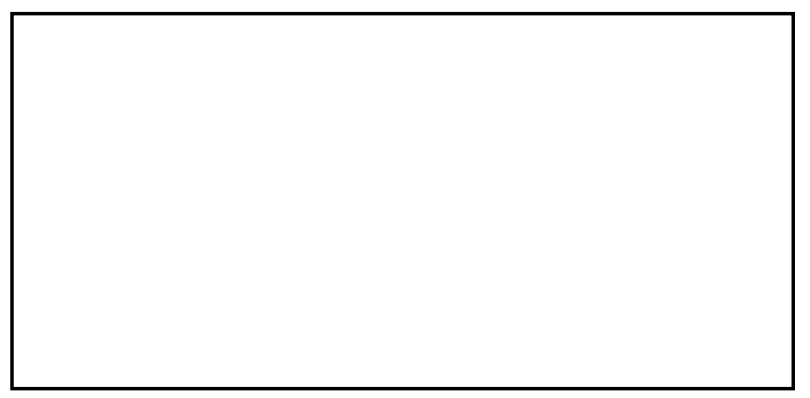

Figure 2: Pupils' drawings organised on two axes. X-axis: personal knowledge-common knowledge, y-axis: personal conception - known system.

Open themes are typical in the teaching and learning of visual arts. Nonetheless, the first theme of this teaching experiment showed that increasing openness in mathematics teaching and learning brought a new kind of investigative and interactive atmosphere to the classroom. The pupils' discussions on infinity, for instance, were particularly rewarding. In the visual arts lesson, the task engaged the pupils in talking about the semiotic features of art and the ways in which images and works of art refer to the prevailing culture. In both tasks, it was possible to distinguish the same path of understanding: making observations, working independently, seeing in new ways and understanding.

\section{Sorting and classifying as methods in visual arts}

'Different methods of making art' is one of the contents listed in the visual arts curriculum for the $7^{\text {th }}$ grade. In connection with this, the second theme of the teaching experiment, 'Sorting and classifying as methods in visual arts', was introduced in the visual arts lesson by exploring contemporary artist Antti Laitinen and his work Forest Square (www.anttilaitinen.com). In this work, Laitinen removed a 10 x 10 metre patch of forest and sorted it into its various materials, such as earth, moss, wood, spruce needles, etc. He then rebuilt the piece of forest by arranging its different materials by colour, texture and form. The pupils were given a similar task within their small groups to identify the different recognisable textures from either a plant with roots or a fruit. They were to reorganise the object by sorting and classifying its textural components and forming a visually interesting piece of work. The whole process was photographed, and the weight and volume of each component was measured. Figure 3 shows the various stages of this work.

This theme combined group work, methods of contemporary art, photography, experimentation, playful learning, composition skills and the use of image processing software. The work resulted in two concepts, equivalence and representation (equivalence relation). Representation is central to learning in visual arts, but also important in mathematics. Moreover, pupils gained experience of intuition-directed work. 


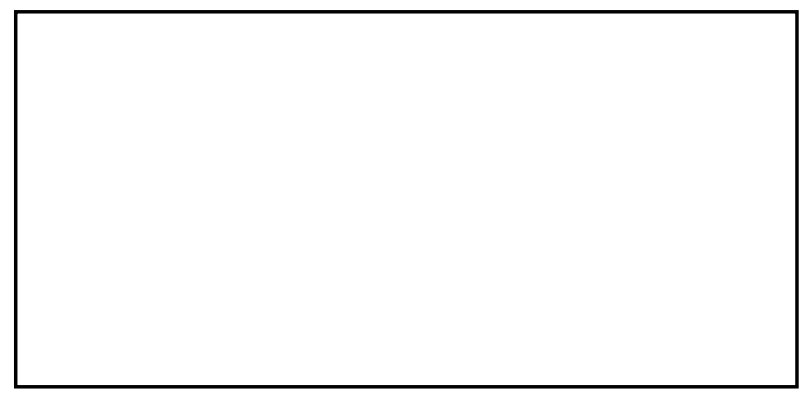

Figure 3: Examples of pupils' work derived from art for the second theme 'Sorting and classifying as methods in visual arts'.

In the mathematics lesson, the key concept was ratio. Based on the measurements made, each group calculated the ratios: how much each textural component weighed compared to the total mass of the plant or the fruit. The findings were reported as fractions, decimal numbers and percentages. Finally, the small groups presented their work to the class, and together with the teacher, discussed sorting and classifying in mathematics. Some pupils were surprised to discover, for example, 'how little the flower is compared to how much soil it needs'. While percentages, fractions and decimal numbers were already familiar to the students, several interesting discussions arose on measurement inaccuracy: 'My percentages don't add up to $100 \%$ '. In this task, mathematical thinking was most clearly evident when pupils were sorting and classifying, even though the pupils did not themselves identify this as mathematics and more likely considered measurements and calculating as real mathematics.

\section{Mosaic}

The Mosaic activity (see [22]) was more extensive than the previously presented two learning continuums. Here, the work steps alternated: sometimes more visual arts, sometimes more mathematics. Some communal mosaic works were completed as a result of this activity, and the last of these was displayed permanently on the school wall. At the beginning of the work, pupils mirrored a pattern and coloured it with different shades of blue (Figure 4).

Figure 4: First work step of the Mosaic - mirroring and colouring. 
When all the patterns were ready, they were organised as a mosaic. The second work step involved cutting out the same pattern from blue and white paper and again organising these as a mosaic (Figure 5).

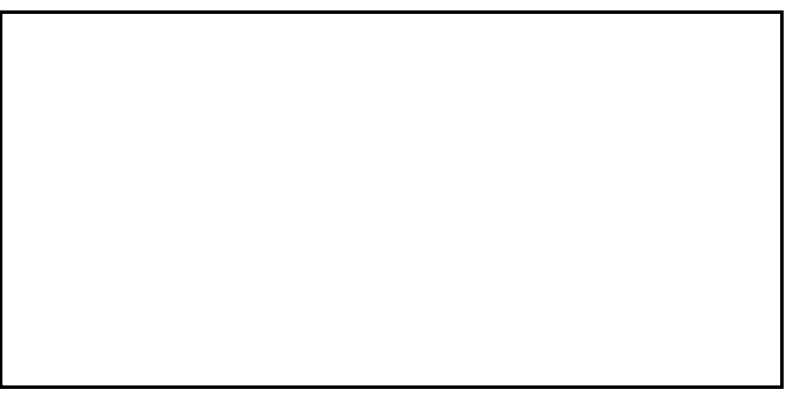

Figure 5: Mirroring and colouring, organised paper cuttings and working with clay.

The third work step introduced the new material, clay. The pieces of mosaic were burnt and glazed with blue and white glaze. During this work, the pupils were able to learn about different mosaic techniques in different cultures (see [22]) and discuss open problems, for example: how can the mosaic maker construct a big square out of four smaller squares, if he is allowed to make only two cuts?

At the end of the work, pupils were grouped into small groups of 2-4 and were asked to construct rhythmic patterns with their mosaic pieces. After a vote, three pieces of work were displayed permanently on the school wall (Figure 6)

The third teaching experiment, 'Mosaic', differed from the previous ones, because the integration was implemented totally in the visual arts class and mathematics and visual arts were not differentiated. On the contrary, all the tasks contained aspects of both subjects. However, the pupils' roles were not the same, the integrative task was designed by the teacher alone and there was less openness in it. The phenomenon was tessellation and Islamic art. Moreover, current refugeeism was discussed and mosaic art was linked with Finnishness by choosing a blue and white colour scheme.

Figure 6: Three pieces of work displayed permanently on the school wall. 


\section{A photograph of oneself and schematic work}

The fourth learning continuum was 'A photograph of oneself and schematic work', which started from a photograph. The digitalised picture was simplified and reduced by using compasses and adding some arcs (Figure 7). After the outlines were finished, the colour theory was introduced and the drawings were coloured with complementary colours. The pupils could choose the colours they wanted and then tinted them with black and white, and mixed them with each other to obtain shaded colours. Finally, all the selfportraits were set next to each other, and together they formed a 'class photo'. The pupils discussed whether they recognised one another from these drawings.

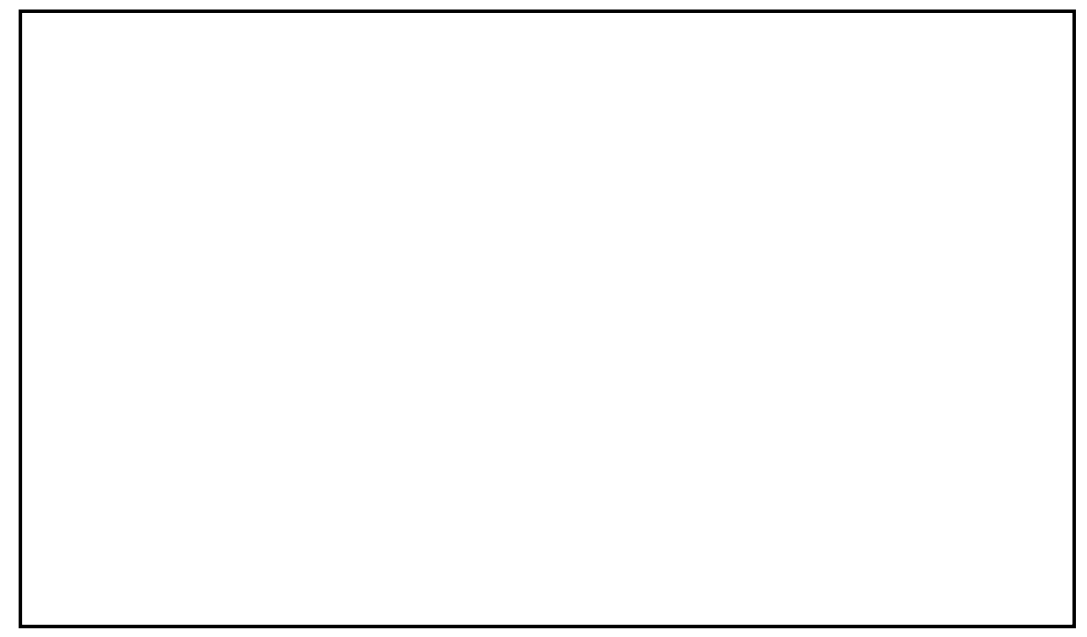

Figure 7: A photograph of oneself-working with compasses and complementary colours.

\section{Summing up the four integrative learning continuums}

In the analysis, we found that all four of Havinga's integrative learning continuums are examples of discipline-based integration. Her starting point was the curriculum and the individual subjects. Another important aspect was the common phenomena. In the first experiment, 'Personal meanings when producing and interpreting integers', the phenomenon was numbers. In mathematics, numbers are an inherent topic, but in visual arts, numbers open up room to discuss expressions, semantics and symbols. The second experiment's phenomenon, 'Sorting and classifying as methods in visual arts', was classification. This is a method for finding ratios in mathematics and a method for organising a certain perception in a visually interesting way in visual arts. The phenomenon in 'Mosaic' is structure, which is a common, central theme in both mathematics and visual arts, and in the fourth learning continuum, 'A photograph of oneself and schematic work', the pivotal phenomenon was simplification.

Integration was sequentially implemented in the first two experiments, with one subject preceding the other. In the last two experiments, it was implemented partially together and partially as separate disciplines in the same classes. (See [8], [6], and [15].) In all these experiments, the teacher encouraged the students to organise their experiences and find regularities around them [20], and promoted social and thinking skills. In the last experiment, she also promoted technology skills [6]. Although Bresler [2] states that only seldom is integration realised equally and cognitively in a meaningful way within subjects, in Havinga's integrative learning continuums, this was the case. 
Table 3: Concepts and processes in integrative learning continuums.

\begin{tabular}{|c|c|c|c|c|}
\hline $\begin{array}{l}\text { Integrative } \\
\text { learning } \\
\text { continuum }\end{array}$ & $\begin{array}{l}\text { Mathematics } \\
\text { Concepts }\end{array}$ & Processes & $\begin{array}{l}\text { Visual arts } \\
\text { Concepts }\end{array}$ & Processes \\
\hline $\begin{array}{l}\text { 1: Personal } \\
\text { meanings when } \\
\text { producing and } \\
\text { interpreting } \\
\text { integers }\end{array}$ & $\begin{array}{l}\text { - the number and } \\
\text { its } \\
\text { representations } \\
\text { - sequence } \\
\text { - infinity }\end{array}$ & $\begin{array}{l}\text { - sorting and } \\
\text { classifying } \\
\text { - finding a rule } \\
\text { - problem- } \\
\text { solving } \\
\text { - mathematical } \\
\text { discussion }\end{array}$ & $\begin{array}{l}\text { - representation } \\
\text { - symbol } \\
\text { - semiotics }\end{array}$ & $\begin{array}{l}\text { - visualisation of } \\
\text { observations and } \\
\text { ideas } \\
\text { - discussing } \\
\text { pictures/images } \\
\text { - comprehending } \\
\text { through hand-making }\end{array}$ \\
\hline $\begin{array}{l}\text { 2: Sorting and } \\
\text { classifying as } \\
\text { methods in visual } \\
\text { arts }\end{array}$ & $\begin{array}{l}\text { - ratio } \\
\text { - fraction } \\
\text { - percentage } \\
\text { - approximation }\end{array}$ & $\begin{array}{l}\text { - measuring and } \\
\text { inaccuracy } \\
\text { - mathematical } \\
\text { discussion }\end{array}$ & - modern art & $\begin{array}{l}\text { - getting to know the } \\
\text { ways in which } \\
\text { contemporary art } \\
\text { works }\end{array}$ \\
\hline 3: Mosaic & $\begin{array}{l}\text { - symmetry } \\
\text { - shape } \\
\text { - mirror image }\end{array}$ & $\begin{array}{l}\text { - mathematical } \\
\text { modelling } \\
\text { - problem- } \\
\text { solving } \\
\text { - mathematical } \\
\text { discussion }\end{array}$ & $\begin{array}{l}\text { - mosaic } \\
\text { - rhythm } \\
\text { - multiculturalism }\end{array}$ & $\begin{array}{l}\text { - working with clay } \\
\text { tiles } \\
\text { - making aesthetic } \\
\text { choices } \\
\text { - working in process- } \\
\text { oriented way }\end{array}$ \\
\hline $\begin{array}{l}\text { 4: A photograph of } \\
\text { oneself and } \\
\text { schematic work }\end{array}$ & $\begin{array}{l}- \text { arc } \\
\text { - radius }\end{array}$ & $\begin{array}{c}\text { - geometric } \\
\text { drawing }\end{array}$ & $\begin{array}{l}\text { - colour theory } \\
\text { - complementary } \\
\text { colours } \\
\text { - tints and shades } \\
\text { - digital image } \\
\text { recognition } \\
\text { - abstract art }\end{array}$ & $\begin{array}{l}\text { - compass drawing } \\
\text { - reducing details } \\
\text { - editing a picture into } \\
\text { an abstract image }\end{array}$ \\
\hline
\end{tabular}

If we focus on concepts and processes in mathematics and visual arts (see Table 3), we notice that several substantive concepts and processes manifest themselves in these experiments. In the next section, we discuss whether these concepts and processes also come true for the mathematics teacher students and pupils participated in these activities.

\section{Are these integrative learning continuums still mathematics?}

As part of the teacher education programme and the methods course for mathematics teacher students, the students $\left(\mathrm{N}_{1}=49\right)$ familiarised themselves with the four teaching experiments above via photos, and discussed what mathematics they could recognise from these activities (see [19]). At the same time, they returned their notes as data. The small groups were productive. Students' personal ideas and the ideas developed further together consisted of 239 items, approximately 4-5 ideas/note. Most of the ideas 163/239 $\approx 68 \%$ concerned mathematical concepts, and $76 / 239 \approx 32 \%$ concerned mathematical processes.

The mathematical concepts were classified (see Table 4) into seven categories: (1) concepts related to geometry, (2) concepts related to numbers, (3) the concept of ratio, (4) the concept of set, (5) the concept of quantity, (6) the concept of function and (7) the concept of infinity. These concepts are part of the $7^{\text {th }}$ grade 
curriculum and it was favourable that future teacher students recognised concepts that were connected in geometry (46.7\%) and in numbers (39.9\%), as these experiments were originally designed correspondingly. Some of the concepts concerning geometry were geometric figures, area, symmetry, angle and similarity. Concerning numbers, teacher students named concepts such as fraction, percentage, opposite number, integers and decimal numbers. The concepts of ratio, set, function and infinity emerged as such. The concept of quantity included, for example, units of measurement.

Table 4: Mathematical concepts named by mathematics teacher students and 9th grade pupils.

\begin{tabular}{lcccc}
\hline \multirow{2}{*}{ Mathematical concepts } & \multicolumn{2}{c}{ Teacher students } & Pupils & \\
& $f$ & $\%$ & $f$ & $\%$ \\
\hline Concepts related to geometry & 76 & $46.7 \%$ & 16 & $36.4 \%$ \\
Concepts related to numbers & 65 & $39.9 \%$ & 25 & $56.8 \%$ \\
Ratio & 9 & $5.5 \%$ & - & $0 \%$ \\
Set & 7 & $4.3 \%$ & - & $0 \%$ \\
Quantity & 2 & $1.2 \%$ & 3 & $6.8 \%$ \\
Function & 2 & $1.2 \%$ & - & $0 \%$ \\
Infinity & 2 & $1.2 \%$ & - & $0 \%$ \\
TOTAL & 163 & $100 \%$ & 44 & $100 \%$ \\
\hline
\end{tabular}

The pupils $\left(\mathrm{N}_{2}=16\right)$, who were now in the $9^{\text {th }}$ grade, looked at the photos of their own work and recalled the activities they took part in two years earlier. They also looked at photos of other pupils' work. After this, they filled in a questionnaire. They found 61 mathematical concepts and processes, approximately $3-4$ ideas/questionnaire. The majority of the ideas $44 / 61 \approx 72 \%$ concerned concepts and $17 / 61 \approx 28 \%$ concerned processes. Unlike the teacher students' suggestions, most of the pupils' ideas concerned numbers (see Table 4). Only the geometrical concepts of shape, figure and symmetry were recognised. As regards numbers, pupils suggested concepts such as opposite number (four mentions), positive and negative numbers (six mentions), number (eight mentions) and digits (two mentions). In the category of quantity, only mass and frequency were mentioned.

The processes were condensed into four categories: (1) working mathematically, (2) geometrical methods, (3) working with numbers and (4) others (see Table 5). The fourth category was quite common among the teacher students, but the pupils' suggestions matched the other three categories.

In the 'working mathematically' category, problem-solving, logical thinking and languaging were mentioned. The first two were also cited in pupils' questionnaire responses. Moreover, teacher students suggested processes such as dividing, ordering, simplifying, drawing, compiling statistics and looking for regularities.

The mathematics teacher students named several geometrical methods: mirroring, conceptualising, geometrics, scaling, measuring and identification of shape. The pupils' suggestions were composing, combining and measuring. In the category of 'working with numbers', teacher students listed presenting the number, rounding the number and ordering the numbers. The pupils mentioned only calculating and counting. The fourth category had many interesting perspectives. From these activities, the teacher students also recognised possibilities to awaken pupils' thoughts and to link mathematics to the pupils' own lives 
and to arts. Some felt that the learning continuums may bring cultural connotations and metaphorical meanings into teaching and affect pupils' experiences of mathematics.

Table 5: Mathematical processes named by mathematics teacher students and 9th grade pupils.

\begin{tabular}{lcccc}
\hline \multirow{2}{*}{ Mathematical processes } & \multicolumn{2}{c}{ Teacher students } & Pupils & \\
& $f$ & $\%$ & $f$ & $\%$ \\
\hline Working mathematically & 30 & $39.5 \%$ & 11 & $64.8 \%$ \\
Geometrical methods & 21 & $27.6 \%$ & 3 & $17.6 \%$ \\
Working with numbers & 12 & $15.8 \%$ & 3 & $17.6 \%$ \\
Others & 13 & $17.1 \%$ & - & $0 \%$ \\
TOTAL & 76 & $100 \%$ & 17 & $100 \%$
\end{tabular}

What meaning did pupils give these integrative learning continuums?

According to their answers, the mathematics and visual arts integrative learning continuums had diversified the pupils' views of mathematics (see [19]). No less than $10 / 16 \approx 63 \%$ were of this opinion.

'It has not changed my former beliefs, but it has brought more perspective to what mathematics can be.' (Girl 6)

'I've learned that maths is related to everything and you can find maths everywhere, you just have to look for it.' (Girl 7)

'I've not realised before that maths is almost everywhere.' (Boy 2)

Three pupils reported that integrative instruction had not changed their opinion of mathematics. Three pupils commented differently.

'No real effect, I still think that maths is just ordinary numerical tasks.' (Boy 1)

To the question 'How have these experiments influenced the ways in which you see mathematics around you?', $10 / 16 \approx 63 \%$ of the pupils answered that they see more mathematics around them. (Girl 8)

'I can think about things differently. I might be able to combine things with maths.'

'Nowadays, I see mathematical stuff around me more easily.' (Boy 2)

However, four pupils answered 'In no way'.

Integrative instruction divided opinions and was critically acclaimed. The exercises seemed to challenge the pupils' understanding of common visual arts education and common school mathematics. As many as $7 / 16 \approx 44 \%$ did not support the integration of mathematics and visual arts, they still saw that it may work for some other subjects.

'I think it can hinder my learning, because in some subjects it's difficult to keep up with even ordinary teaching.' (Girl 6)

'I don't think it's useful, because you're not able to focus on one subject.' (Girl 5) 
'In my opinion, it can sometimes confuse your understanding of things, to some extent at least.' (Boy 2)

'It's probably good for some subjects. But not for maths and visual arts.' (Boy 5)

Only two pupils thought that integration was worth trying.

'I think it's just ok. It's nice to see the same things in chemistry, for example, that are also in maths, so you can understand it a bit better.'(Boy 3)

\section{Discussion}

When we build interdisciplinary, discipline-based integrative learning continuums in basic education (7th9th grade), it is important to do so how in a way that equally takes into account the nature of each subject and the typical ways in which to build knowledge. Our results indicate that when the considered phenomenon is sufficiently open, collaborative learning brings together the whole class, pupils and the teacher, and motivates them all to learn. The openness of tasks and the teaching of mathematics by emphasizing identity work are the factors that brought a new perspective to the teaching situations for both the students and teachers, and enabled them to have learning experiences together [see also 11]. Such phenomena may be related to concepts that many disciplines have in common, such as representation or relationship. They may also be dynamic and related to the acquisition of more disciplinary knowledge or knowledge regarding building processes, such as sorting and classification, or they may concentrate on the different natures of the disciplines being integrated. Our experiences have shown that it is essential that conceptual thinking is the starting point when planning integrative instruction.

For most school subjects, the integrative art education model suggested by Räsänen [21] could work as a premise. The observations, emotions, forms representing each field, as well as cultural symbols can act as unifying factors in the learning continuums that the teachers construct [21]. It is essential that we do not forget pupils' identity work, and that we pause to reflect on it. Is there something in the pupils' lives or everyday events that can be identified as mathematical order or disorder? Is there something a pupil can observe, describe and model with mathematical tools? Such documentation and collection of data is also involved in many works of contemporary art and their creative processes.

When mathematics is integrated with visual arts education, together they form different parallel ways of observing reality. In multidisciplinary learning continuums, this both enriches and obscures the pupil's images of mathematical concepts and processes. Mathematics teacher students found a great deal of mathematics in these multidisciplinary learning continuums. In contrast, pupils' perceptions of mathematics were still very narrow, and mainly concerned calculations. Working mathematically did not look the same for them as for the future teachers. Both the teacher students' and the pupils' answers revealed that mathematical concepts were easier to perceive than mathematical processes. The teacher students also mentioned that within integrative learning continuums it is possible to invite pupils' reflections, to connect mathematics to pupils' lives and arts, to awaken cultural connotations and affective experiences. These features were passed on to the teacher students as spectators not taking part in these experiments, but the pupils themselves did not mention them as mathematical attributes. Here we note that multidisciplinary teaching experiments may integrate subjects in ways that challenge pupils' perceptions of the subjects.

The pupils reported that the experiments had diversified their understanding of mathematics and several pupils mentioned that the integration of the subjects helped them see mathematics in a new light and in new places. In this way, the integration seemed to promote the pupils' ability to detect the 'invisible' objects of mathematics (see [15]). At the same time, the pupils reacted critically to multidisciplinary learning continuums and doubted their usefulness for their own learning. They expressed concern that it is 'hard to keep track' in these subjects in the first place, even when learned separately. We can ask whether pupils 
regard the comparison between different ways of knowing as meaningful learning? Or does it merely serve to confuse their thinking?

Integrating arts education and mathematics challenges Tall's [25] view of learning mathematics. In a multidisciplinary, knowledge-based learning continuum, concepts and processes are placed in parallel with each other. This increases the pupils' own talk of mathematics, spontaneous questions about the concepts, reflection and creative solutions. It also challenges their previous views of mathematics. However, it does not seem to straightforwardly support learning of mathematical concepts and learning processes, at least not in the pupil's mind.

Integrative instruction does not consist of merely doing familiar things in different ways, but of doing something genuinely different. The strength and usefulness of integrative learning continuums as pedagogical tools is that they construct meaning, rather than espousing meanings given by others. Of the teacher, this requires a new kind of agency in teaching. The teacher is no longer just an expert of their subject, and therefore, pupils' experiences of and benefits from integration depend greatly on how the teacher succeeds in creating meaningful learning activities [1], [14].

Concerning the reliability of the study, it should be noted that the experiments carried out here were of a unique nature. We admit that it is rare that the teacher who designs these experiments is a teacher of both visual arts and mathematics. She was thus able to build these integrative learning continuums in the view that both subjects are equally valued and important. The experiments were not carried out for research purposes only, but were part of her professional development as a teacher, and her aspiration to meet the challenges of the curriculum. The classes were her own and she was not able to influence her study groups. The timetable sometimes imposed constraints on planning the implementation. Taking this into consideration, and in order to be able to implement similar experiments in schools, teachers must have enough time for planning and should be encouraged to see their subjects in a new way.

Hinde [14] suggests that when designing integrative instruction, teachers should remember and retain the nature of the subjects and challenge their pupils with authentic, but not too strange, difficult or even impossible tasks. The activities should be meaningful, and they should not hinder the objectives of the subjects. This is a real challenge for teaching and learning in multidisciplinary learning continuums. The teacher needs to clarify her/his subject's standpoint, so that each subject in question redeems their place in the pupils' minds. In this clarification, the pivotal, joint concepts and processes of the subjects are central.

\section{References}

[1] J.A. Beane, Curriculum integration and the disciplines of knowledge, Phi Delta Kappan 76 (1995), pp. $616-622$.

[2] L. Bresler, The subservient, co-equal, affective, and social integration styles and their implications for the arts, Arts Education Policy Review 96:5 (1995), pp. 31-37.

[3] T. Brown, Mathematics Education and Language. Interpreting Hermeneutics and Post-Structuralism, Kluwer Academic Publishers, Netherlands, 2001.

[4] H. Cantell, Ainejakoisuus ja monialainen eheyttäminen opetuksessa [Discipline-based and multidisciplinary integration in teaching], in Näin rakennat monialaisia oppimiskokonaisuuksia, $\mathrm{H}$. Cantell, ed, PS-kustannus Bookwell Oy, Juva, 2015, pp.11-15.

[5] FNBE. Finnish National Board of Education, National Core Curriculum for Basic Education 2014, Finnish National Board of Education, Helsinki, 2014. Available at http://www.oph.fi/english/curricula_and_qualifications/basic_education.

[6] R. Fogarty, Ten ways to integrate curriculum, Educational Leadership 49:2 (1991), pp. 61-65. 
[7] V. Font, J. D. Godino, and J. Gallardo, The emergence of objects from mathematical practices, Educational Studies in Mathematics 82:1 (2013), pp. 97-124.

[8] R. Gresnigt, R. Taconis, H. van Keulen, K. Gravemeijer, and L. Baartman, Promoting science and technology in primary education: a review of integrated curricula, Studies in Science Education 50:1 (2014), pp. 47-84.

[9] I. Halinen and L. Jääskeläinen, Opetussuunnitelmauudistus 2016, Sivistysnäkemys ja opetuksen eheyttäminen [The reform of the National Core Curricula for Pre-primary Education and for Compulsory Basic Education 2016, General Education and Integrating], in Näin rakennat monialaisia oppimiskokonaisuuksia, H. Cantell, ed. PS-kustannus Bookwell Oy, Juva, 2015, pp. 19-36.

[10] M. Havinga and P. Portaankorva-Koivisto, Kuvataiteen ja matematiikan yhteisiä ilmiöitä etsimässä [Looking for common phenomena in visual arts and mathematics teaching], in Matematiikan ja luonnontieteiden opetuksen tutkimusseuran julkaisuja, H. Silfverberg and P. Hästö, eds., 2016, pp. $12-$ 22. Available at http://www.protsv.fi/mlseura/julkaisut/MALU2015_Final.pdf.

[11] M. Havinga, YHDESSÄ VAI ERIKSEEN? Opetuskokeilu kuvataidekasvatuksen ja matematiikan opetuksen integraatiosta perusopetuksen seitsemännellä luokalla [TOGETHER OR SEPARATELY? Teaching experiment in integrating visual arts and mathematics in $7^{\text {th }}$ grade basic education], Master thesis, Aalto University School of Arts, Design and Architecture, 2015.

[12] M. Havinga and P. Portaankorva-Koivisto, Visual Arts and Mathematics Education: Looking for Integrative Phenomena, in Proceedings of Bridges 2016: Mathematics, Music, Art, Architecture, Education, Culture, 2016, pp. 79-86). Available at http://archive.bridgesmathart.org/2016/bridges2016-79.html.

[13] M. Havinga and Portaankorva-Koivisto, P. Kuvataide ja matematiikka - yhdessä ja erikseen [Visual arts and mathematics - together or separately], in Ainedidaktisia julkaisuja 11, Uudistuva ja uusiutuva ainedidaktiikka, H-M. Pakula, E. Kouki, H. Silfverberg, \& E. Yli-Panula, eds., 2016, pp. 175-190. Available at https://helda.helsinki.fi/handle/10138/174336.

[14] E. T. Hinde, Revisiting curriculum integration: A fresh look at an old idea, The Social Studies 96:3 (2005), pp. 105-111.

[15] M. M. Hurley, Reviewing integrated science and mathematics: The search for evidence and definitions from new perspectives, School Science and Mathematics 101 (2001), pp. 259-268.

[16] M. Hähkiöniemi, Teacher's reflections on experimenting with technology-enriched inquiry-based mathematics teaching with a preplanned teaching unit, The Journal of Mathematical Behavior 32:3 (2013), pp. 295-308.

[17] K. Juuti, S. Kairavuori, and S. Tani, Tiedonalalähtöinen eheyttäminen [Discipline-based integration], in Näin rakennat monialaisia oppimiskokonaisuuksia, H. Cantell, ed. PS-kustannus Bookwell Oy, Juva, 2015, pp. 77-93.

[18] P. Portaankorva-Koivisto, Elämyksellisyyttä tavoittelemassa - narratiivinen tutkimus matematiikan opettajaksi kasvusta [In Search of Lived Experiences -a Narrative Research on the Growth Process of Becoming a Teacher of Mathematics], Ph.D. diss., University of Tampere, 2010.

[19] P. Portaankorva-Koivisto and M. Havinga, Oppilaiden ja opettajaopiskelijoiden kokemuksia matematiikan ja kuvataiteen oppimiskokonaisuuksista [Pupils' and student teachers' views on mathematics and visual arts integrating learning continuums], in Suomen ainedidaktisen tutkimusseuran julkaisuja [Publications of the Finnish Research Association for Subject Didactics], in review process.

[20] L. J. Rennie, G. J. Venville, and J. Wallace, Integrating Science, Technology, Engineering, and Mathematics: Issues, Reflections, and Ways Forward, Routledge, New York, NY, 2012. 
[21] M. Räsänen, Taide, taitaminen ja tietäminen - kokonaisvaltaisen opetuksen lähtökohtia [Arts, to Know-how, and Knowing - Bases for Holistic Education], Synnyt/Origins online publication, 3 (2010), pp. 48-61.

[22] R. Sarhangi. “A Workshop in Geometric Constructions of Mosaic Designs.” Proceedings of Bridges 2010: Mathematics, Music, Art, Architecture, Culture, (2010), pp. 531-538.

[23] A. Sfard, On the dual nature of mathematical conceptions: Reflections on processes and objects as different sides of the same coin, Educational studies in mathematics 22:1 (1991), pp. 1-36.

[24] D. Tall, Thinking through three worlds of mathematics, in Proceedings of the 28th Conference of the International Group for the Psychology of Mathematics Education (2004), vol. 4, pp. 281-288.

[25] D. Tall, Building theories: The three worlds of mathematics, For the learning of mathematics 24:1 (2004), pp. 29-32.

[26] D. Tall, The transition to formal thinking in mathematics, Mathematics Education Research Journal 20:2 (2008), pp. 5-24.

[27] S. Tani, K. Juuti, and S. Kairavuori, Integrating geography with physics and visual arts: Analysis of student essays, Norsk Geografisk Tidsskrift - Norwegian Journal of Geography 67:3 (2013), pp. 172178. 